\section{Normal phenotype and partial trisomy for the $G$ positive region of chromosome 21}

SUMMARY A prenatally diagnosed male fetus and his mother, who was referred because of her advanced age, both carried an abnormal bisatellited chromosome 21 as an extra chromosome. The abnormal 21 was monocentric and the $\mathrm{G}$ negative band $\mathrm{q} 22$ and part of $\mathrm{q} 21$ had been deleted during formation. The phenotype of both the mother and child (at birth) was normal.

A number of published reports have supported the view that the phenotype of Down's syndrome can be present only with a trisomy of the long arm distal region of chromosome 21. These reports arise from essentially three groups of chromosome 21 abnormalities: discordant segregation of interstitially deleted chromosomes 21 (cases 1 and 2 of Aula et al., 1973; Cervenka et al., 1977); segregation of reciprocal translocations involving $21 \mathrm{q}$ (case 4 of Aula et al., 1973; Williams et al., 1975); and tandem translocations (Warkany and Soukup, 1963; Soudek et al., 1966; Niebuhr, 1974; Hagemeijer and Smit, 1977).

The chromosome abnormality in the subjects of the present report is a corollary of the above statement, namely that there is an essentially normal phenotype expressed in probands with trisomy of the proximal part of the $\mathrm{G}$ positive band $21 \mathrm{q} 21$.

\section{Materials and methods}

$\mathrm{G}$ and $\mathrm{C}$ bands were prepared as described previously (Daniel and Lam-Po-Tang, 1976). N-banding was by the abbreviated method of $18 \mathrm{~h}$ incubation in $50 \%$ aqueous $\mathrm{AgNO}_{3}$ at $50^{\circ} \mathrm{C}$ and counterstaining with $2 \%$ Giemsa.

\section{Case report}

The proband was a prenatally screened male fetus who, at birth, had a normal phenotype with none of the stigmata of Down's syndrome. The referral for prenatal diagnosis was made on the grounds of advanced maternal age (40 years). The mother had no previous obstetric history as this was her first pregnancy. She was a trained nurse of normal intelligence and appearance, and she too had the

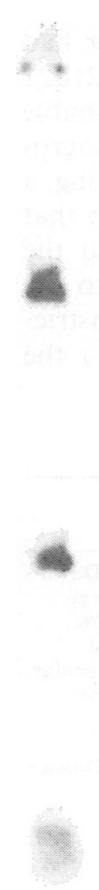

mar
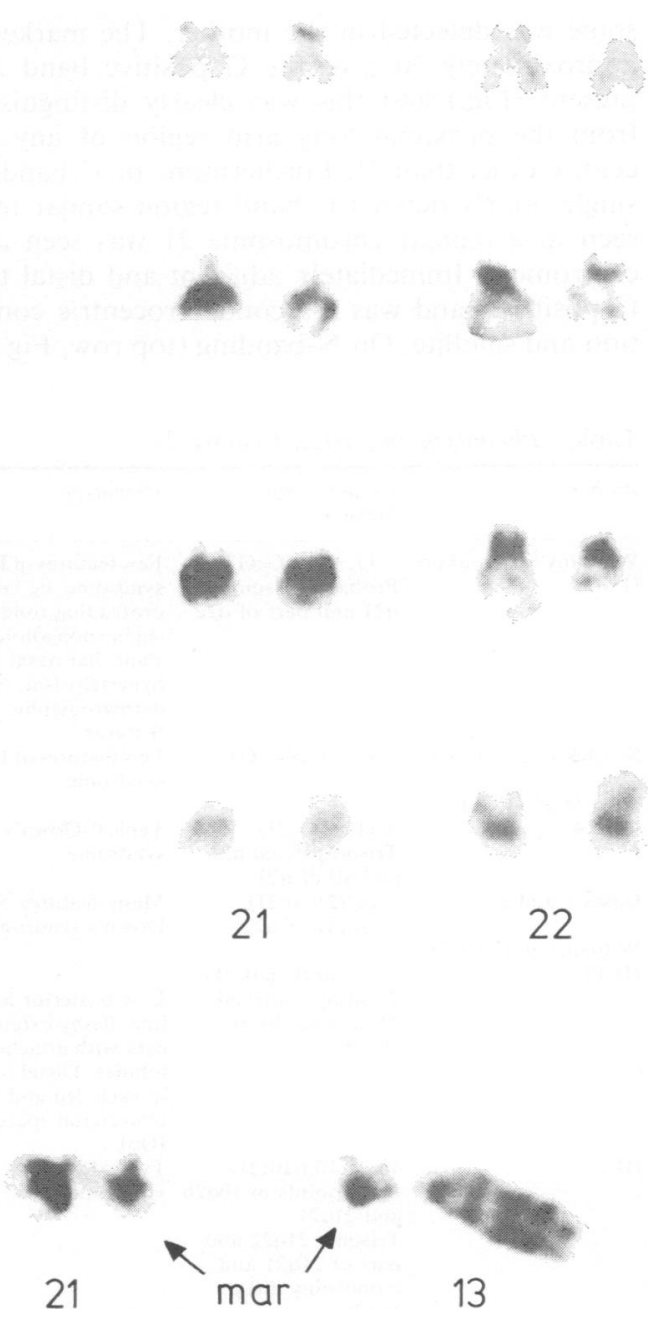

Fig. Bisatellited marker chromosome present as an extra chromosome in two normal individuals. Top 4 rows; marker and pairs 21 and 22. Top row, $N$ bands showing $N$ band positive long arm of marker; rows 2 and $3, G$ bands, long arm satellite visible; row $4, C$ bands showing marker with single $C$ band block. Bottom row, satellite association of long arm of marker with a $21 p$ (left) and short arm of marker with a $13 p$ (right). 
chromosome abnormality. It was concluded that the abnormality was compatible with a normal phenotype and the pregnancy was continued. A male sib of the mother had normal chromosomes, but the maternal grandparents were not available for study.

\section{CHROMOSOME STUDIES}

All clones detected prenatally in the proband had 47 chromosomes with an extra bisatellited chromosome smaller than a normal 21. A similar extra chromosome was detected in the mother. The marker had approximately $70 \%$ of the $G$ positive band $21 \mathrm{q} 21$ present (Fig.) and this was clearly distinguishable from the proximal long arm region of any acrocentric other than 21 . Furthermore, on C-banding, a single poorly defined $\mathrm{C}$ band region similar to that seen in a regular chromosome 21 was seen at the centromere. Immediately adjacent and distal to the $G$ positive band was a second acrocentric constriction and satellite. On N-banding (top row, Fig.), the

Table Phenotype in partial trisomy 21.

\begin{tabular}{|c|c|c|}
\hline Authors & $\begin{array}{l}\text { Chromosomal } \\
\text { imbalance }\end{array}$ & Phenotype \\
\hline $\begin{array}{l}\text { Warkany and Soukup } \\
\text { (1963) }\end{array}$ & $\begin{array}{l}-G,+\tan (G ; G) \\
\text { Probably trisomy of } \\
q 21 \text { and part of } q 22\end{array}$ & $\begin{array}{l}\text { Few features of Down's } \\
\text { syndrome, eg large } \\
\text { protruding tongue, } \\
\text { slight mongoloid } \\
\text { slant, flat nasal bridge, } \\
\text { hypertelorism. No } \\
\text { dermatogylphic } \\
\text { features }\end{array}$ \\
\hline Soudek et al. (1966) & $-\mathbf{G},+\tan (\mathbf{G} ; \mathbf{G})$ & $\begin{array}{l}\text { Few features of Down's } \\
\text { syndrome }\end{array}$ \\
\hline \multicolumn{3}{|l|}{ Aula et al. (1973) } \\
\hline Case 4 & $\begin{array}{l}\text { der } 15, \mathrm{t}(15 ; 21) \\
\text { Trisomy distal q21 } \\
\text { and all of } \mathrm{q} 22\end{array}$ & $\begin{array}{l}\text { Typical Down's } \\
\text { syndrome }\end{array}$ \\
\hline Cases 1 and 2 & $\begin{array}{l}+\operatorname{del}(21)(\mathrm{q} 21) \\
\text { Trisomy of } \mathrm{q} 22\end{array}$ & $\begin{array}{l}\text { Many features of } \\
\text { Down's syndrome }\end{array}$ \\
\hline \multicolumn{3}{|c|}{ Williams et al. (1975) } \\
\hline III.18 & $\begin{array}{l}47,+ \text { der } 21, \mathrm{t}(10 ; 21) \\
\text { Trisomy proximal } \\
21 \mathrm{q} 21 \text { and distal } \\
10 \mathrm{q} 26\end{array}$ & $\begin{array}{l}\text { Low posterior hair- } \\
\text { line, fleshy external } \\
\text { ears with attached } \\
\text { lobules. Distal loops } \\
\text { in each 3rd and 4th } \\
\text { interdigital space. } \\
\text { IQ61 }\end{array}$ \\
\hline III.5 & $\begin{array}{l}46, \text { der } 10, t(10 ; 21) \\
\text { Breakpoints in } 10 \mathrm{q} 26 \\
\text { and } 21 \mathrm{q} 21 \\
\text { Trisomy } 21 \mathrm{q} 22 \text { and } \\
\text { part of } 21 \mathrm{q} 21 \text { and } \\
\text { monosomy distal } \\
10 \mathrm{q} 26\end{array}$ & $\begin{array}{l}\text { Typical Down's } \\
\text { syndrome }\end{array}$ \\
\hline $\begin{array}{l}\text { Hagemeijer and Smit } \\
\text { (1977) }\end{array}$ & $\begin{array}{l}-21+\tan (21 ; 21) \\
\text { Trisomy for all of } \\
21 q 21\end{array}$ & $\begin{array}{l}\text { Moderate mental } \\
\text { retardation, epicanthic } \\
\text { folds, flat nasal bridge, } \\
\text { open mouth, and short, } \\
\text { broad hands }\end{array}$ \\
\hline $\begin{array}{l}\text { Present case } \\
\text { bJE } \\
815 / 77\end{array}$ & $\begin{array}{l}+ \text { der } 21, t(21 ; ?) \\
\text { (q21;p12) (identity } \\
\text { of second acrocentric } \\
\text { unknown) } \\
\text { Trisomy of } 270 \% \\
21 q 21\end{array}$ & $\begin{array}{l}\text { Mother and male } \\
\text { child of normal } \\
\text { intelligence and } \\
\text { appearance }\end{array}$ \\
\hline
\end{tabular}

terminal long arm satellited region was $N$ positiv in many cells. The $G$ band morphology was asym $\oplus$ metrical, indicating that it was unlikely to be tandem $t(21 ; 21)$, and was most probably the resulto of a reciprocal translocation between a 21 , with break within $\mathrm{q} 21$, and another acrocentric with proximal p12 breakpoint.

\section{Discussion}

This case is further confirmation for the hypotheses of Aula et al. (1973), Niebuhr (1974), and Williams et al. (1975) that a trisomy for the distal segment q2 of chromosome 21 is required for the expression of typical Down's syndrome. Other cases relevant to this argument are shown in the Table. The case op Hagemeijer and Smit (1977) is the most similar to the present case. That case and the patient (III.18N of Williams et al. (1975) with trisomy for most of q2 6 had few features of Down's syndrome but were mentally retarded. The present case with a trisomy for the proximal (?) half of 21q11 had a normaE phenotype with no retardation and this contributes to the emerging pattern. There is a noticeables clinical similarity between the cases of Hagemeijexo and Smit (1977) and Warkany and Soukup (1963) with only a few features of Down's syndrome, fors example, mental but not physical retardation, large protruding tongue, flat nasal bridge, and little else The patients in the present report represent a furthero stage of minimising the effect of extra chromosome $21 \stackrel{2}{\longrightarrow}$ material on the phenotype. The larger issue of the probable paucity of structural genes within regions that are $G$ positive must await documentation.

\section{ARThUR DANIEL \\ Cytogenetics and Cell Biology Unit: Prince of Wales Hospital, Sydney, Australia}

\section{References}

Aula, P., Leisti, J., and Von Koskull, H. (1973). Partiaf trisomy 21. Clinical Genetics, 4, 241-251.

Cervenka, J., Gorlin, R. J., and Djavadi, G. R. (1977). Downo syndrome due to partial trisomy 21q. Clinical Genetics, 11, 119-121.

Daniel, A., and Lam-Po-Tang, P. R. L. C. (1976). Structure and inheritance of some heterozygous Robertsonian $N$ translocations in man. Journal of Medical Genetics, 13, N 381-388.

Hagemeijer, A., and Smit, E. M. E. (1977). Partial trisomy 21 further evidence that trisomy of band $21 \mathrm{q} 22$ is essential foro Down's phenotype. Human Genetics, 38, 15-23.

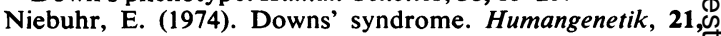
99-101.

Soudek, D., Laxova, R., and Adamek, R. (1966). Development of translocation 21/22. Lancet, 2, 336-337.

Warkany, J., and Soukup, S. W. (1963). A chromosoma雨 abnormality in a girl with some features of Down's栭 syndrome (mongolism). Journal of Pediatrics, 62, 890-894. 
Williams, J. D., Summitt, R. L., Martens, P. R., and Kimbrell, R. A. (1975). Familial Down's syndrome due to $t(10 ; 21)$ translocation: evidence that the Down phenotype is related to trisomy of a specific segment of chromosome 21 . American Journal of Human Genetics, 27, 478-485.

Requests for reprints to A. Daniel, Cytogenetics Unit, Prince of Wales Hospital, High and Avoca Streets, Randwick, NSW 2031, Australia.

Trisomy $20 \mathrm{p}$ from maternal $\mathrm{t}(3 ; 20)$ translocation 1

SUMMARY A case of trisomy 20 p resulting from a maternal translocation $\mathrm{t}(3 ; 20)$ is described. QM and BUdR banding techniques were used for its identification. A round face with oblique palpebral fissures, strabismus, cardiac and vertebral abnormalities, mild psychomotor retardation, together with poor co-ordination and speech impediment, are the most typical features of the proband.

Few cases of trisomy 20p are to be found in published reports. Recently, Centerwall and Francke (1977)

${ }^{1}$ This work was supported by grant $780061583-$ CNR Rome: Program of preventive medicine; project perinatal medicine. documented 3 new cases in the same family and reviewed the other 10 reported cases belonging to 5 families. In all cases the trisomy was the result of anomalous segregation of balanced parental translocation.

In this paper we report a case of trisomy $20 p$ resulting from a balanced maternal translocation $t(3 ; 20)$ segregating in a large family.

\section{Case report}

The subject is a female, born 1.1 .74 , at 38 weeks' gestation, to a gravida 1 mother, after a gravidic toxaemia which complicated the end of the pregnancy. The mother and father were 23 and 31 years old, respectively, at the time of her birth. Though the child was born after a normal delivery, she had mild fetoneonatal distress. Birthweight was $2750 \mathrm{~g}$. Haemodynamic studies showed Fallot's tetralogy.

On physical examination after surgery at 4 years of age she had: normal weight and height, microcephaly $(<3$ rd centile), round face, short upward slanting palpebral fissures with downward displacement of the medial corner, moderate hypertelorism, short nose with large nares, and bilateral convergent strabismus (Fig. 1).

According to the Terman-Merrill scale, there was psychomotor retardation of 1 year compared to a normal subject which, 5 months later, appeared greatly improved (retardation of 6 months). The

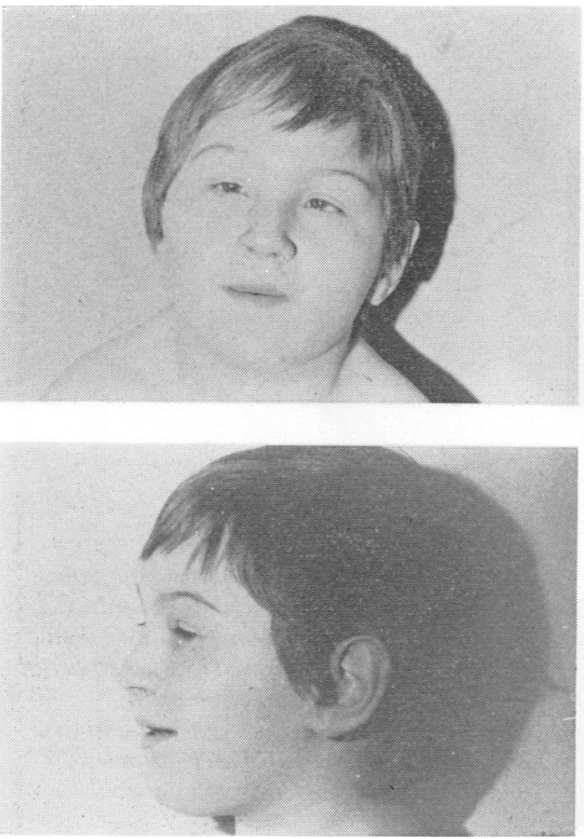

Fig. 1 The proband at the age of $4 \frac{1}{2}$ years. 